\title{
$\alpha \beta$-Double Negative CD4/CD8 (CD56) T cell (DNTs) in metastatic melanoma: basal frequency and behaviour during Ipilimumab treatment. Preliminary evaluations
}

\author{
Giacoma De Tullio ${ }^{1 *}$, Sabino Strippoli ${ }^{2}$, Rosa Angarano ${ }^{1}$, Vincenza De Fazio ${ }^{1}$, Nicola Sgherza ${ }^{1}$, Antonio Negri ${ }^{1}$,
} Anna Albano ${ }^{2}$, Pasquale lacopino ${ }^{1,3}$, Attilio Guarini $^{1}$, Michele Guida ${ }^{2}$

From Melanoma Bridge Meeting 2014

Naples, Italy. 03-06 December 2014

\section{Background}

The knowledge of the immune system role on melanoma has accelerated the translation of key advancements into medical breakthroughs like ipilimumab, an anti-CTLA4 immunomodulating antibody. Ipilimumab works amazingly well only in a limited number of patients and its effects on T-cell subpopulations as well as on immune response remains to be elucidated. Recently, it was described a new subset of immunomodulating T-cells, known as Double-negative T-cells (DNTs) expressing either $\alpha \beta$ or $\gamma \delta$ T-cell receptors (TCR) but lacking CD4, CD8,CD56. The DNTs contribute specifically to antitumor immunity since involved in immune regulation and tolerance acting as regulatory T-cells (Treg) and/or cytotoxic T-cells and they contribute to in vivo anti-melanoma immunity as previously reported [1-5]. However no data are available on their frequency in melanoma, as well as the effects of ipilimimumab on DNTs functional attitude in immunomodulation and on modulating their expression during the therapy. We aimed to evaluate the modulation of DNT frequency in Metastatic Melanoma (MM) patients treated with ipilimumab during the therapy in order to explore their potential role on clinical outcome and therapy response.

\section{Patients and methods}

We carried out flow cytometric studies and statistical analyses on data of frequency of DNTs from 136 individuals,

${ }^{1}$ Hematology Unit, National Cancer Research Centre,Istituto Tumori "Giovanni Paolo II",Bari - Italy;

Full list of author information is available at the end of the article which included 16 healthy donors, $30 \mathrm{MM}$ patients who received ipilimumab as second line therapy, and 90 lymphoma patients. To evaluate the modulation of DNT during ipilimumab therapy we collected peripheral blood of MM subset at three time points: 1 . Before start of therapy, 2. Before the 3th ipilimumab infusion, 3. After 2 months from the end of therapy. All patients provided their informed consent in accordance with the Declaration of Helsinki.

\section{Results}

We observed a significant decrease $(\mathrm{p}=0.001)$ of circulating $\alpha \beta$-DNT frequency in MM (13.49cells/ul \pm 5.4$)$ as compared with healthy controls (31.3cells/ul \pm 3.4 ) and more interestingly when compared with Lymphoma patients $(p=0.001)$ (fig.1). Furthermore, $\alpha \beta$-DNTs was significantly increased $(\mathrm{p}=0.048)$ in MM patients with ECOG performance status $\leq 1$ as compared with $>1$ (fig.2). Finally, despite a low cluster was collected until the last time point sample, we observed a trend of significant increasing $(\mathrm{p}=0.083)$ in $\alpha \beta$-DNTs during the ipilimumab treatment (fig.3).

\section{Conclusions}

This is the first report on evaluation of $\alpha \beta$-DNTs in MM patients and their modulation by an immunomodulating drug such as ipilimumab. Our preliminary data suggested a lower frequency of $\alpha \beta$-DNTs and a worse immunological impairment in MM compared to healthy and lymphoma subject as well as a trend of increasing of this T-cell population during the therapy. These results, supported by future studies, could estabilish the 


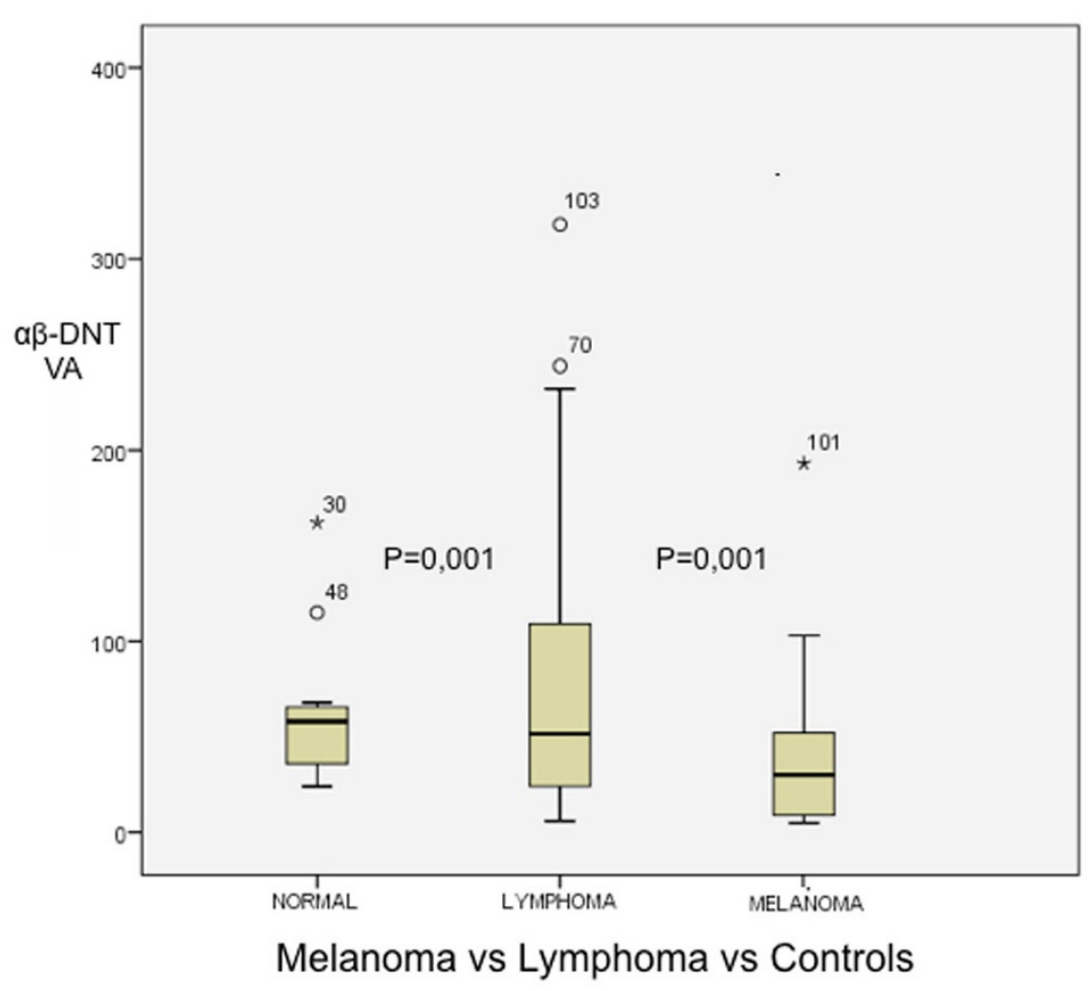

Fig 1 Circulating $\alpha \beta$-DNT frequency in Melanoma patients as compared with healthy controls and Lymphoma patients $P=0,048$

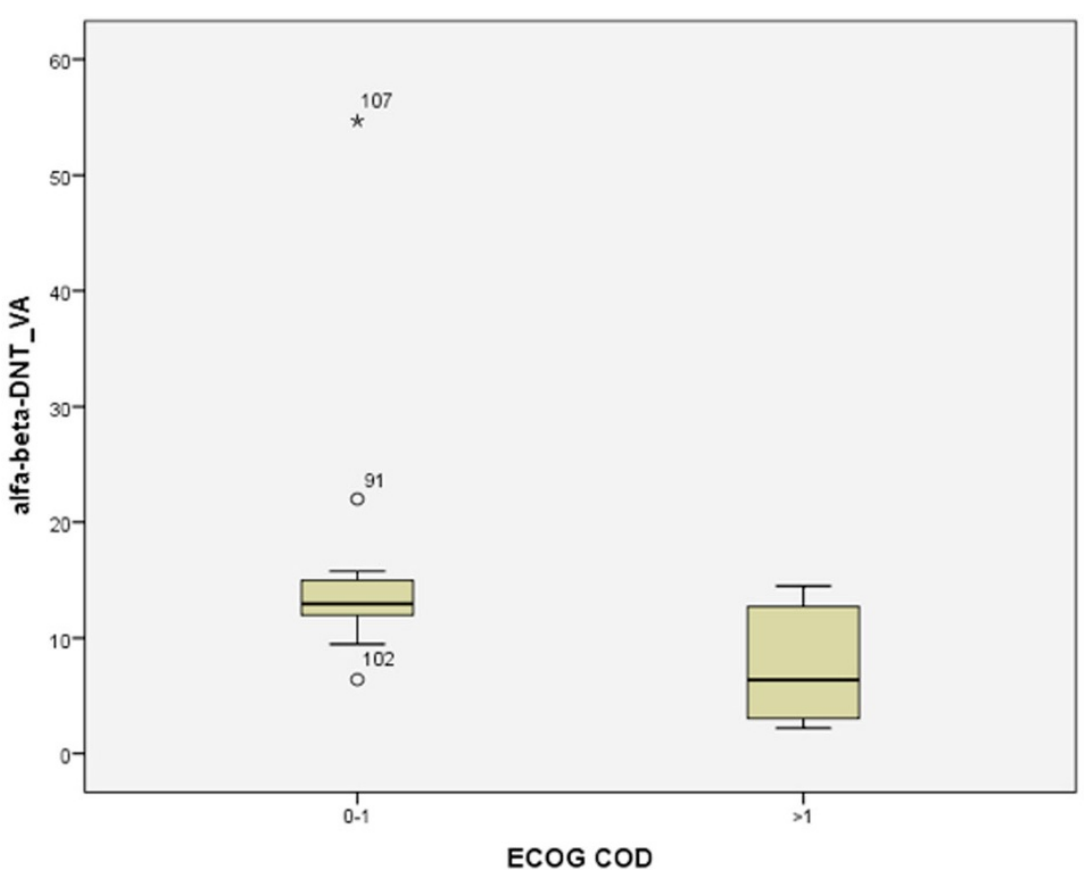

Fig 2 Circulating $\alpha \beta$-DNT frequency in Melanoma patients based of ECOG performance status. 


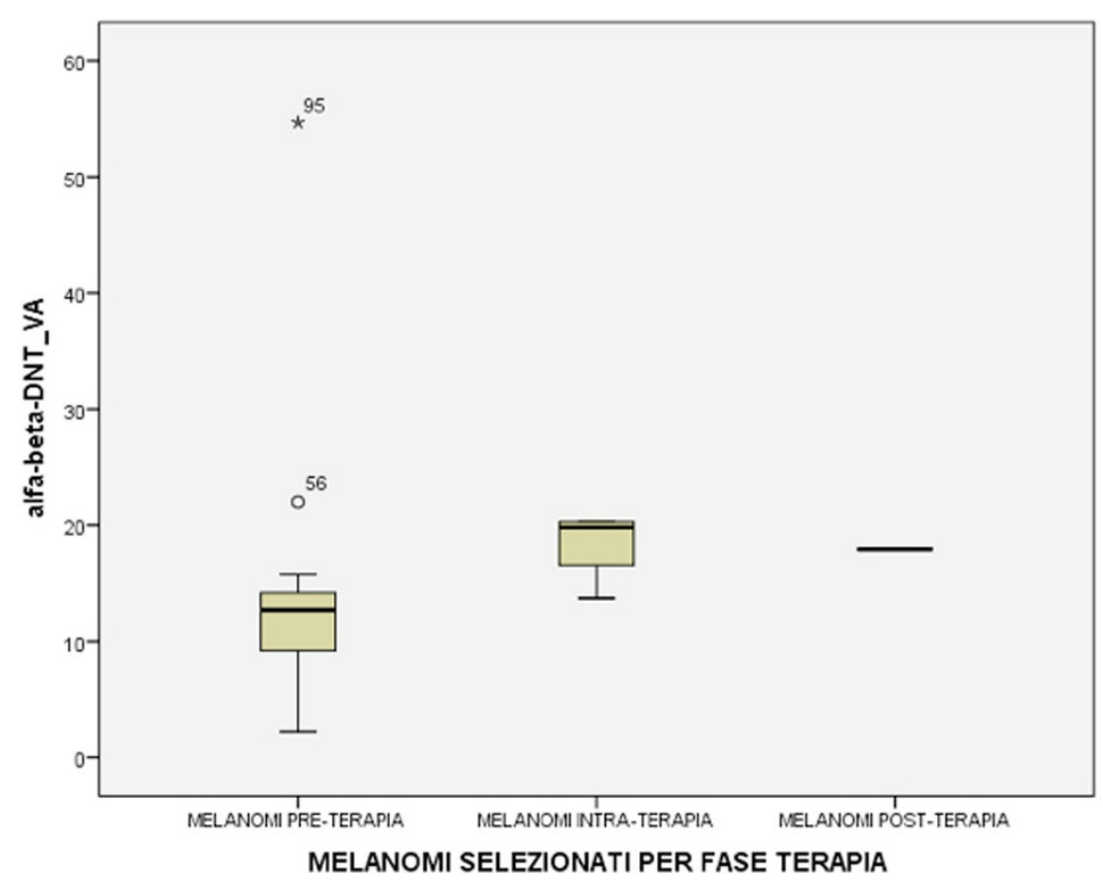

Fig 3 Circulating $\alpha \beta$-DNT frequency in Melanoma patients during the Ipilimumab treatment

role of DNTs in MM patients and the significance of their increase during ipilimumab therapy.

\section{Authors' details}

'Hematology Unit, National Cancer Research Centre,Istituto Tumori "Giovanni Paolo II",Bari - Italy: . ${ }^{2}$ Medical Oncology Department National Cancer Research Centre, Istituto Tumori "Giovanni Paolo II", Bari - Italy; ${ }^{3}$ Clinical Institute "Prof. R. De Blasi", Reggio Calabria 89100, Italy.

Published: 15 January 2015

\section{References}

1. Golden EB, Frances D, Pellicciotta I, Demaria S, Barcellos-Hoff MH, Formenti SC: Radiation fosters dose-dependent and chemotherapyinduced immunogenic cell death. Oncolmmunology 2014, 3:e28518.

2. Formenti SC, Demaria S: Combining radiotherapy and cancer immunotherapy: a paradigm shift. Journal of the National Cancer Institute 2013, 105(4):256-265.

3. Demaria S, Kawashima N, Yang AM, Devitt ML, Babb JS, Allison JP, Formenti SC: Immune-mediated inhibition of metastases after treatment with local radiation and CTLA-4 blockade in a mouse model of breast cancer. Clin Cancer Res 2005, 11(2):728-734.

4. Postow MA1, Callahan MK, Barker CA, Yamada Y, Yuan J, Kitano S, Mu Z, Rasalan T, Adamow M, Ritter E, Sedrak C, Jungbluth AA, Chua R, Yang AS, Roman RA, Rosner S, Benson B, Allison JP, Lesokhin AM, Gnjatic S, Wolchok JD: Immunologic correlates of the abscopal effect in a patient with melanoma. N Engl J Med 2012, 366:925-931.

5. Golden EB, Demaria S, Schiff PB, Chachoua A, Formenti SC: An abscopal response to radiation and ipilimumab in a patient with metastatic nonsmall cell lung cancer. Cancer immunology research 2013, 1(6):365-372.

6. Demaria S, Ng B, Devitt ML, Babb JS, Kawashima N, Liebes L, Formenti SC: lonizing radiation inhibition of distant untreated tumors (abscopal effect) is immune mediated. Int I Radiat Oncol Biol Phys 2004, 58(3):862-870.

7. Formenti SC, Demaria S: Systemic effects of local radiotherapy. Lancet Oncol 2009, 10(7):718-726.
8. Ruocco MG, Pilones KA, Kawashima N, Cammer M, Huang J, Babb JS, Liu M, Formenti SC, Dustin ML, Demaria S: Suppressing T cell motility induced by anti-CTLA-4 monotherapy improves antitumor effects. J Clin Invest 2012, 122(10):3718-3730.

9. Groh V, Wu J, Yee C, Spies T: Tumour-derived soluble MIC ligands impair expression of NKG2D and T-cell activation. Nature 2002, 419(6908):734-738.

10. Jinushi M, Hodi FS, Dranoff G: Therapy-induced antibodies to MHC class I chain-related protein $A$ antagonize immune suppression and stimulate antitumor cytotoxicity. Proc Natl Acad Sci U S A 2008, 103(24):9190-9195.

11. Gasser S, Orsulic S, Brown EJ, Raulet DH: The DNA damage pathway regulates innate immune system ligands of the NKG2D receptor. Nature 2005, 436(7054):1186-1190.

\section{doi:10.1186/1479-5876-13-S1-010}

Cite this article as: De Tullio et al:: $\alpha \beta$-Double Negative CD4/CD8 (CD56) T cell (DNTs) in metastatic melanoma: basal frequency and behaviour during Ipilimumab treatment. Preliminary evaluations. Journal of Translational Medicine 2015 13(Suppl 1):010.

\section{Submit your next manuscript to BioMed Central and take full advantage of:}

- Convenient online submission

- Thorough peer review

- No space constraints or color figure charges

- Immediate publication on acceptance

- Inclusion in PubMed, CAS, Scopus and Google Scholar

- Research which is freely available for redistribution 